H O M E R' S

TRADITIONAL ART 


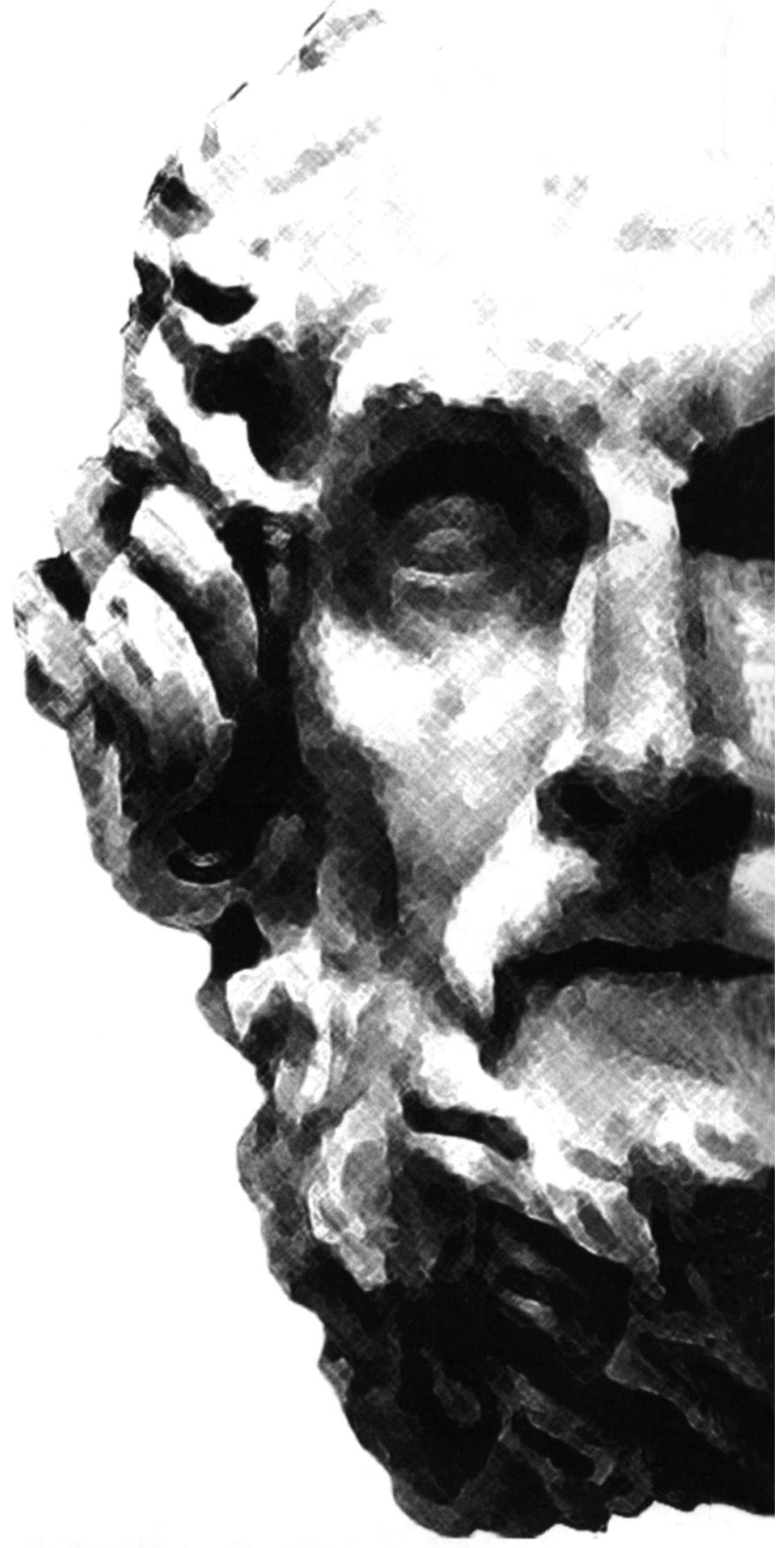




\section{JOHN MILES FOLEY}

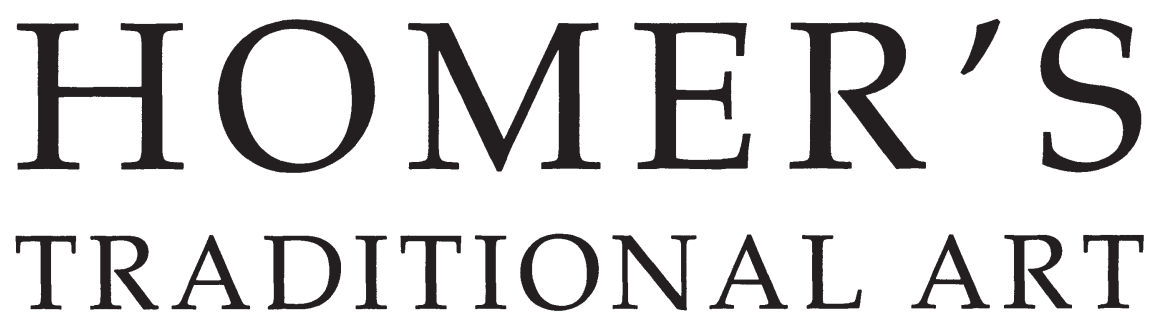

The Pennsylvania State University Press University Park, Pennsylvania 
Library of Congress Cataloging-in-Publication Data

Foley, John Miles, 1947-

Homer's traditional art / John Miles Foley.

p. $\quad \mathrm{cm}$.

Includes bibliographical references and index.

ISBN 0-271-01870-4 (alk. paper)

1. Homer-Technique. 2. Epic poetry, Greek-History and

criticism. 3. Oral-formulaic analysis. 4. Oral tradition-Greece.

5. Rhetoric, Ancient. I. Title.

PA4175.F65 1999

$883 \cdot .01-\mathrm{dc} 21$

98-51850

CIP

Copyright $@ 1999$ The Pennsylvania State University

All rights reserved

Published by The Pennsylvania State University Press,

University Park, PA 16802-1003

It is the policy of The Pennsylvania State University Press to use acid-free paper for the first printing of all clothbound books. Publications on uncoated stock satisfy the minimum requirements of American National Standard for Information Sciences-Permanence of Paper for Printed Library Materials, ANSI Z39.48-1992. 


\section{To the memory of \\ Hannah Frances Foley Kelly}

For all my days remaining 


\section{"To Homer" John Keats}

Standing aloof in giant ignorance, Of thee I hear and of the Cyclades, As one who sits ashore and longs perchance To visit dolphin-coral in deep seas.

So thou wast blind;-but then the veil was rent, For Jove uncurtain'd heaven to let thee live, And Neptune made for thee a spumy tent, And Pan made sing for thee his forest-hive; Aye on the shores of darkness there is light, And precipices show untrodden green, There is a budding morrow in midnight, There is a triple sight in blindness keen; Such seeing hadst thou, as it once befel To Dian, Queen of Earth, and Heaven, and Hell. 